Abstracta Iranica Abstracta Iranica

Revue bibliographique pour le domaine irano-aryen

Volume 30 | 2010

Comptes rendus des publications de 2007

\title{
Il rosso e il nero e la rivoluzione della modernità. Breve storia del pensiero iraniano contemporaneo. Roma, Aracne, 2007, 327 p.
}

\section{Paola Rivetti}

\section{(2) OpenEdition}

1 Journals

Édition électronique

URL : http://journals.openedition.org/abstractairanica/38095

DOI : 10.4000/abstractairanica.38095

ISSN : 1961-960X

Éditeur :

CNRS (UMR 7528 Mondes iraniens et indiens), Éditions de l'IFRI

Édition imprimée

Date de publication : 8 avril 2010

ISSN : 0240-8910

Référence électronique

Paola Rivetti, « II rosso e il nero e la rivoluzione della modernità. Breve storia del pensiero iraniano

contemporaneo. Roma, Aracne, 2007, 327 p. », Abstracta Iranica [En ligne], Volume 30 | 2010, document 300, mis en ligne le 08 avril 2010, consulté le 26 septembre 2020. URL : http://

journals.openedition.org/abstractairanica/38095; DOI : https://doi.org/10.4000/abstractairanica 38095

Ce document a été généré automatiquement le 26 septembre 2020.

Tous droits réservés 


\title{
Il rosso e il nero e la rivoluzione della modernità. Breve storia del pensiero iraniano contemporaneo. Roma, Aracne, 2007, 327 p.
}

\author{
Paola Rivetti
}

1 Le livre d'Andrea Duranti, doctorant en histoire et relations internationales de l'Afrique et de l'Asie à l'Université de Cagliari paraît à un moment où les études sur l'Iran contemporain en Italie ne sont pas encore nombreuses. L'ouvrage vaut donc déjà pour son opportunité. Il est en outre appréciable pour sa tentative de présentation et d'analyse de la pensée politique iranienne depuis la Révolution constitutionelle jusqu'à nos jours. L'A. couvre cette période en suivant la succession chronologique des événements, desquels il fournit un panorama complet. Mais l'A. ne se limite pas à la pensée politique: particulièrement louable est l'attention qu'il porte aussi à la littérature et au marché éditorial iranien, avec un regard particulière sur la littérature féminine.

2 Duranti envisage, dans son ouvrage, les vicissitudes historiques complexes, qui suscitent de vives et sérieuses controverses historiographiques; on regrette d'autant plus que l'A. ne donne aucune indication et ne précise pas sa position sur ces débats. En outre, la reproduction de longs extraits d'un nombre limité de monographies trahit un défaut de critique des sources. De même, l'utilisation presque exclusive de sources secondaires constitue l'une des principales faiblesses de l'ouvrage.

3 En plus de ces défauts, on relève un certain nombre d'imprécisions voire d'inexactitudes: définition erronée des fonctions constitutionnelles du Conseil des Experts (pp.169-170), analyse lacunaire de la ligne politique du Daftar-e Tahkim-e Vaḥdat (p. 181), usage approximatif des mots «fondamentaliste» et «intégriste», ici considérés comme synonymes, ainsi que du terme « modernité ». 
4 Malgré ses défauts, le livre de Duranti représente un bon indicateur de l'intérêt que ce champ d'investigation commence à susciter en Italie, en même temps qu'un point de départ pour des recherches ultérieures.

INDEX

Thèmes : 13.1. Iran

\section{AUTEURS}

PAOLA RIVETTI

Italie 